\title{
Estudo da Mortalidade na fratura do Fêmur Proximal em idosos
}

\author{
Study of the proximal femoral fractures mortatlity in elderly patients
}

Marcos Hideyo Sakaki ${ }^{1}$, Arnóbio Rocha Olivelra², Fabríclo F Coelho ${ }^{3}$,

Luiz Eugênio Garcez Leme

\section{RESUMO}

Foi feito um estudo de revisão sobre a mortalidade na fratura do fêmur proximal em idosos com base nas publicações mais relevantes do período de 1998 a 2002. Foram incluídos 25 artigos relacionados ao assunto, selecionados com base nos bancos de dados Medline e Cochrane, totalizando 24.062 pacientes com mais de 60 anos de idade, que tiveram fratura do fêmur proximal. Quatorze estudos foram prospectivos, oito retrospectivos e três revisões sistemáticas. As taxas médias de mortalidade foram de 5,5\% durante a internação hospitalar, 4,7\% ao fim de um mês de seguimento, 11,9\% com três meses, 10,8\% com seis meses, $19,2 \%$ com um ano e $24,9 \%$ com dois anos.

Foram identificados quatro fatores intimamente relacionados com uma maior mortalidade nestes pacientes: idade avançada, grande número de doenças associadas, sexo masculino e presença de deficiências cognitivas. Outros fatores mostraram uma fraca correlação com a mortalidade como capacidade deambulatória prévia, índice de risco anestésico da Sociedade Americana de Anestesia (ASA), anemia, hipoalbuminemia, linfopenia e existência de AVC prévio. Os fatores como tempo prévio à cirurgia, tipo de anestesia utilizada e tipo de osteossíntese empregada não mostraram ter interferência.

Descritores: Fraturas do fêmur; Idoso, Mortalidade.

\section{SUMMARY}

A revision study was performed on the proximal femoral fractures mortality in elderly patients, based on the most relevant publications during the 1998 to 2002 period. Twenty-five articles related to the subject were included, selected from the Medline and Cochrane databases, totaling 24.062 patients over the age of 60 years, with fracture of the proximal femur. There were 14 prospective trials, 8 retrospective and 3 were systematic reviews. The mean in-hospital mortality was 5,5\%, 1-month mortality 4,7\%, 3-months 11,9\%, 6-months 10,8\%, 1-year 19,2\% and 2years $24,9 \%$.

Four factors were identified in these patients closely related with a larger number of deaths: advanced age, polymorbidity, male gender and the presence of cognitive impairment. Other factors, such as a pre-fracture walking ability, ASA score, hemoglobin level, albumin level, lymphocyte count and a previous stroke demonstrated poor correlation with mortality. Finally, factors like time-to-surgery, anesthetic techniques and type of osteosynthesis, had no effect on mortality.

Keywords: Femoral fractures, Aged, Mortality
Trabalho realizado no Instituto de Ortopedia e Traumatologia do Hospital das Clínicas da Faculdade de Medicina da Universidade de São Paulo.

1. Medico Assistente do Instituto de Ortopedia e Traumatologia do Hospital das Clínicas da Faculdade de Medicina da Universidade de São Paulo, aluno em nível de doutorado do Curso de Pós Graduação da FMUSP.

2. Médico, aluno em nível de doutorado do Curso de Pós Graduação da FMUSP. 3. Aluno em nível de mestrado do Curso de Pós Graduação da FMUSP.

4. Professor Doutor da Faculdade de Medicina da Universidade de São Paulo, Coordenador de Curso de Pós Graduação do Departamento de Ortopedia e Traumatologia da FMUSP.

5. Mestre em Medicina, Diretor Clínico do Instituto de Ortopedia e Traumatologia do Hospital das Clínicas da FMUSP.

6. Professor Titular e Chefe do Departamento de Ortopedia e Traumatologia da Faculdade de Medicina da Universidade de São Paulo, Coordenador de Curso de Pós Graduação do Departamento de Ortopedia e Traumatologia da FMUSP

Endereço para correspondência:Rua Professor Ovídio Pires de Campos, 333, CEP 05403-010 São Paulo, SP - Luiz Eugênio Garcez Leme - lueglem@usp.br

Trabalho recebido em 19/02/2004. Aprovado em 05/07/2004
Work performed at the Institute of Orthopedics and Traumatology of the Clinics Hospital of the Medicine School of the São Paulo University - FMUSP

1 - Assistant Physician at the Institute of Orthopedics and Traumatology of the Clinics Hospital of the Medicine School of the São Paulo University, Doctorate Postgraduate Student - FMUSP

2- Physician, Doctorate Postgraduate Student - FMUSP

3- Mastership Postgraduate Student -FMUSP

4 -Professor Doctor at the Medicine School of the São Paulo University; Coordinator of the Postgraduate Course of the Department of Orthopedics and Traumatology FMUSP

5 -Master in Medicine, Clinical Director of the Institute of Orthopedics and Traumatology of the Clinics Hospital- FMUSP

6 - Chairmain and Head of the Department of Orthopedics and Traumatology of the Medicine School of the São Paulo University. Coordinator of the Postgraduate Course at the Department of Orthopedics and Traumatology- FMUSP

address: Luiz Eugênio Garcez Leme - lueglem@usp.br 


\section{INTRODUÇÃO}

A fratura do fêmur proximal é uma causa comum e importante de mortalidade e perda funcional ${ }^{(12,14,25)}$. A incidência deste tipo de fratura aumenta com a idade ${ }^{(1)}$, devido principalmente ao aumento do número de quedas associado a uma maior prevalência de osteoporose. É mais comumente relacionada com idosos moradores nas áreas urbanas, de sexo feminino e institucionalizados.

Com o aumento da expectativa de vida e conseqüentemente com a maior proporção de idosos na população, principalmente os chamados grandes idosos (aqueles com mais de 80 anos), a importância deste tipo de fratura tem aumentado nos últimos anos ${ }^{(6)}$. Na Inglaterra e País de Gales foram internados, no biênio 1997/1998, sessenta e seis mil idosos com fratura do fêmur ${ }^{(6)}$, enquanto que nos Estados Unidos estima-se que ocorram anualmente 350.000 fraturas do fêmur, com um custo total de aproximadamente 6 bilhões de dólares por ano, só em cuidados clínicos ${ }^{(14)}$

O custo social e econômico da fratura de fêmur eleva-se ainda mais pelo fato de que após um período de tempo variável de internação o paciente idoso enfrenta altas taxas de mortalidade, necessitando de cuidados médicos intensivos e programas de reabilitação por longos períodos ${ }^{(14)}$. Em estudos recentes, pacientes idosos com fratura do fêmur proximal alcançaram a capacidade prévia de realizar as tarefas diárias em apenas $17 \%$ das vezes após 4 meses e somente $43 \%$ readquiriram a anterior capacidade de deambulação(24)

Além do prejuízo social decorrente da fratura de fêmur, o idoso tem sua reserva funcional diminuída e apresenta um número grande de doenças crônicas associadas, com $70 \%$ dos pacientes tendo pelo menos duas outras doenças no momento da fratura(24) estando, pois, muito mais sujeito a complicações no pós-operatório tanto imediato quanto tardio, apresentando em média três complicações, que em $26 \%$ dos casos são graves, levando a um risco aumentado de morte ${ }^{(24)}$.

A fratura do fêmur proximal pode ser intracapsular ou extracapsular. No primeiro tipo estão as fraturas do colo femoral e no segundo as fraturas trans-trocanterianas, sendo que ambas decorrem de traumas de baixa energia, como quedas. O grande aumento de incidência destas fraturas na faixa etária acima dos 65 anos deve-se principalmente à instalação da osteoporose, bem como à maior incidência de quedas nesta faixa etária. Apesar de medidas como prevenção de quedas, tratamento precoce da osteoporose, incentivo à atividade física regular e controle de outras doenças, as fraturas femorais no idoso continuam sendo muito freqüentes.

O tratamento da maioria destas fraturas é cirúrgico, sendo o conservador reservado somente a algumas fraturas incompletas ou sem desvio. A cirurgia visa a redução e fixação estável da fratura, utilizando os mais variados métodos de osteossíntese ou, no caso específico da fratura do colo femoral com desvio, a substituição protética. Ao longo do tempo, novos materiais de osteossíntese têm sido desenvolvidos. As placas de comprimento fixo tipo Jewett e Muller, outrora utilizadas no tratamento das fraturas trans-trocanterianas, foram substituídas pelas deslizantes, tipo DHS, ou pelas sínteses intramedulares como o pino tipo gamma e o PFN (Proximal Femoral Nail). Estas sínteses proporcionam uma fixação mais rígida e segura, permitindo um

\section{INTRODUCTION}

The fracture of the proximal femur is a common and important cause of mortality and functional loss $(12,14,25)$. The incidence of this type of fracture with age ${ }^{(1)}$, due mainly to the increase in the number of falls associated to a larger osteoporosis prevalence. It is more commonly related with senior females, resident in the urban areas and institutionalized.

With the increase of the life expectancy and consequently with the largest proportion of seniors in the population, mainly the so-called "big" seniors (those with more than 80 years), the importance of this type of fracture has been increasing in the last years ${ }^{6}$. In England and Wales, in the biennium 1997/1998, sixty six thousand seniors were hospitalized with a fracture of the femur ${ }^{(6)}$, while in the United States it was considered that 350.000 fractures of the femur occurred annually, with a total cost of approximately 6 billion dollars a year, in medical care only(14).

The social and economical cost of the femur fracture is still higher due to the fact that after a period of variable time of hospitalization, the senior patient faces high mortality rates, requiring intensive care doctors and rehabilitation programs during long periods ${ }^{(14)}$. In recent studies, senior patients with a fracture of the proximal femur reached the previous capacity to accomplish the daily tasks in only $17 \%$ of the cases after 4 months, and only $43 \%$ reacquired the previous walking capacity ${ }^{(24)}$.

Besides the social damage due to the femur fracture, the senior had reduced functional reservation and presented a large number of associated chronic diseases, with $70 \%$ of the patients tending towards at least two other diseases at the moment of the fracture(24) being, therefore, much more subject to complications in the postoperative period, so much immediate as late, presenting three complications, that were serious in $26 \%$ of the cases on average, taking an increased risk of death ${ }^{(24)}$.

The fracture of the proximal femur can be intracapsular or extracapsular. In the first type are the fractures of the collum femoris and, in the second, the trans-trochanterian fractures, and both elapse from traumas due to low energy, such as falls. The great increase in the incidence of these fractures in the age group above 65 years of age is due mainly to the installation of the osteoporosis, as well as to the largest incidence of falls in this age group. In spite of the fall prevention measures, precocious treatment of the osteoporosis, incentives to physical activities to regulate and control other diseases, the femoral fractures in the elderly are still very frequent.

The treatment of most of these fractures is surgical, the conservative treatment being reserved only for some incomplete fractures or fractures without deviation. The surgery seeks the reduction and stable fixation of the fracture, using the most varied osteosynthesis methods or, in the specific case of the fracture of the collum femoris with deviation, the prosthetic substitution. Along the time, new osteosynthesis materials have been developed. The fixed length plates of the Jewett and Muller type, formerly used in the treatment of the trans-trochanterian fractures, were substituted by the sliding plates, of the DHS type, or by the intramedular syntheses, as the gamma type pin and PFN (Femoral Proximal Nail). These syntheses provide a more rigid and safe fixation, allowing to precociously start the march, and a smaller degree of mechanical complications in the postoperative peri- 
início de marcha mais precoce e menor grau de complicações mecânicas no pós-operatório. Além disso, a agressão cirúrgica necessária ao implante do material de síntese vem diminuindo progressivamente. As próteses de quadril, utilizadas no tratamento das fraturas do colo femoral, também vêm evoluindo com a utilização de novos materiais e desenhos, visando um menor índice de complicações no pós-operatório.

A literatura sobre mortalidade na população idosa após os vários tipos de fraturas de fêmur proximal e a associação destas aos vários tipos de tratamentos existentes, tanto clínicos quanto cirúrgicos é extensa. O objetivo deste trabalho é fazer uma revisão da literatura recente (1998 a 2002) dos trabalhos mais significativos sobre a mortalidade nos idosos com fratura do fêmur proximal.

\section{MÉTODO}

A pesquisa foi realizada na base de dados MEDLINE, utilizando-se como termos de busca, mortalidade, morbidade, fatores prognósticos e pacientes geriátricos, tendo sido limitada aos últimos cinco anos (artigos publicados desde 1998). Alguns estudos foram selecionados com base nas referências bibliográficas dos trabalhos indicados pelo MEDLINE. Também foi feita uma busca na base de dados COCHRANE com os mesmos parâmetros acima referidos, procurando-se revisões sistemáticas e ensaios clínicos randomizados sobre fatores prognósticos relacionados à mortalidade após fratura de fêmur na população geriátrica.

Especial atenção foi dada para que os 40 trabalhos constantes nas três revisões sistemáticas ${ }^{(2,19,20)}$ não fossem considerados isoladamente, o que certamente acarretaria erro sistemático nos dados obtidos.

Os trabalhos encontrados com a pesquisa foram analisados pelos revisores Sakaki, Oliveira e Coelho, independentemente, e selecionados dando-se a preferência aos trabalhos publicados nas revistas de maior impacto, segundo os critérios do Journal of Citation Report (JCR) do tipo prospectivos e randomizados. Quando houve dúvida com referência a algum artigo, a mesma foi resolvida por consenso. Não foi feita avaliação de concordância. Alguns trabalhos retrospectivos também foram selecionados pois apresentavam uma casuística significante. Três revisões sistemáticas foram incluídas por tratarem de temas importantes relacionados com a mortalidade na fratura do fêmur nos idosos.

O número de mortos em vários períodos após terem sofrido uma fratura do fêmur proximal foi compilado em uma tabela, juntamente com o número total de pacientes idosos estudados, permitindo calcular-se a taxa global de mortalidade. Vários fatores correlatos à mortalidade foram identificados e serão discutidos posteriormente.

\section{RESULTADOS}

O número de trabalhos selecionados foi 25 , totalizando 24.062 pacientes estudados com idade maior de 60 anos que tiveram fratura do fêmur proximal. Foram 14 trabalhos prospectivos, 8 retrospectivos e 3 revisões sistemáticas. Os dados relativos à mortalidade estão expostos na Tabela 1. A taxa de mortalidade durante a internação hospitalar foi de 5,5\%, com um od. Besides, the necessary surgical aggression to the implant of the synthesis material is decreasing progressively. The hip prostheses, used in the treatment of the fractures of the collum femoris, are also being developing with the use of new materials and layouts, seeking a smaller index of complications during the postoperative period.

The literature about mortality in the elderly population after the several types of fractures of the proximal femur, and the association of these to the several existing types of treatments, both clinical and surgical is very extensive. The objective of this work is to do a revision of the recent literature (1998 to 2002) of the most significant works about the mortality in the elderly with fracture of the proximal femur.

\section{METHOD}

The research was performed in the MEDLINE database, using as search terms the words: mortality, morbosity, prognostic factors and geriatric patients, being limited to the last five years (articles published since 1998). Some studies were selected based on the bibliographical references of the works indicated by MEDLINE. A research was also made in the COCHRANE database, with the same parameters as referred above, seeking systematic revisions and clinical randomized assays about prognostic factors related to the mortality after femur fracture in the geriatric population.

Special attention was given so that the 40 works included in the three systematic revisions ${ }^{(2,19,20)}$ were not considered separately, what certainly would result in a systematic mistake within the data obtained.

The works found with that research were analyzed by the reviewers Sakaki, Oliveira, and Coelho independently, and selected with the preference for the works published in the higher impact magazines, according to JCR (Journal of Citation Report) criteria, of the prospective and randomized type. In case of doubt, the article was selected by consensus. Agreement evaluation was not performed. Some retrospective works were also selected because they presented a significant casuistry. Three systematic revisions were included as they dealt with important themes related to the mortality in the fracture of the femur in the elderly.

The number of deaths in several periods after fracturing the proximal femur was compiled in a table, together with the total number of senior patients studied, allowing calculating the global mortality rate. Several factors related to mortality were identified and will be discussed later.

\section{RESULTS}

The number of selected works was 25, totaling 24.062 patients with age above 60 years, which had a fracture of the proximal femur studied. There were 14 prospective works, 8 retrospective and 3 systematic revisions. The data related to the mortality are presented in Table 1 . The mortality rate during hospitalization was 5,5\%; one month after the fracture 4,7\%; three months after 11,9\%; six months after 10,8\%; a year after 19,2\%, and 


\begin{tabular}{|c|c|c|c|c|c|c|c|c|c|c|c|c|}
\hline $\begin{array}{l}\text { Autor } \\
\text { Author }\end{array}$ & Tp & $\mathbf{N}^{0}$ pts & f i-hosp & f 1 m & $2 \mathrm{~m}$ & $3 \mathbf{m}$ & & f $6 \mathrm{~m}$ & $\begin{array}{l}+1 \text { ano } \\
t+1 \text { year }\end{array}$ & $\begin{array}{l}+1 \text { ano } \\
t+1 \text { year }\end{array}$ & $\begin{array}{l}\text { Fat ñ det. p/ † } \\
\text { Non-det.fact.f/ }\end{array}$ & $\begin{array}{l}\text { Fat det. } p / \text { ' } \\
\text { Det. Fact. F }\end{array}$ \\
\hline Raunest & $\mathrm{P}$ & 278 & 21 & & & & & & 76 & & & idade, DA \\
\hline willig & $\mathrm{P}$ & 200 & & $4,5 \%>c$ & & $6 \%>c$ & & & $3,5 \%>c$ & $4,5 \%>c 2 a$ & & \\
\hline Carson & $\mathrm{P}$ & 84 & & & 7 & & & & & & & \\
\hline Ravilkunar & $P$ & 290 & & & & & & & & $\begin{array}{ll}13 \text { anos } 81 \% \text { FI } & 85 \% \text { APQ } 91 \% \text { ATQ } \\
13 \text { years } 81 \% \text { FI } & 85 \% \text { APQ } 91 \% \text { ATQ }\end{array}$ & $\begin{array}{l}\text { tipo de tto cir. } \\
\text { Type of cir.tto }\end{array}$ & \\
\hline Gruson & $\mathrm{P}$ & 395 & 8 & & & 13 & & 25 & 35 & & & anemia \\
\hline van Balen & $\mathrm{P}$ & 102 & & & & & 20 & & & & & Idade/age, CD, DA \\
\hline Iuusko & $\mathrm{P}$ & 120 & & & & 7 & & & 17 & & & Reabilitação/ reabilitation \\
\hline Alarcón & $\mathrm{P}$ & 89 & 5 & & & 19 & & & & & & $\mathrm{CD}$ \\
\hline Forster & $\mathrm{P}$ & 13 & 4 & & & & & 6 & 7 & & & \\
\hline Cree & $\mathrm{P}$ & 558 & & & & 45 & & & & & & Idade/age, $\mathrm{CD}$, sexo/gender \\
\hline Hannan & $\mathrm{P}$ & 571 & 9 & & & & & 77 & & & & $\begin{array}{l}\mathrm{CD}, \mathrm{DA} \text {, deambulação prévia } \\
\mathrm{CD}, \mathrm{DA} \text {, previus deambulation }\end{array}$ \\
\hline Fransen & $\mathrm{P}$ & 565 & & & & & & & & 138 pts. em 2 anos/years & & Sexo/Gender \\
\hline Meyer & $\mathrm{P}$ & 248 & & & & & & 24 & 32 & $28,2 \% \mathrm{em} 3,5$ anos $/$ years & & $\begin{array}{l}\mathrm{CD}, \mathrm{DA}, \text { deambulação prévia } \\
\mathrm{CD}, \mathrm{DA} \text {, previus deambulation }\end{array}$ \\
\hline Chariyalertsk & $\mathrm{P}$ & 330 & 7 & & & & & & 56 & & & $\begin{array}{l}\text { idade, sexo, } \mathrm{DA} \text {, deambulação prévia } \\
\text { age, gender, } \mathrm{DA}, \text { previus, } \\
\text { deambulation }\end{array}$ \\
\hline Davidson & $\mathrm{R}$ & 329 & & & & & & & & 85 pts. em 2 anos / years & & Sexo/gender \\
\hline Dzupa & $\mathrm{R}$ & 244 & & & & & & & 85 & & & $\begin{array}{l}\text { idade, sexo, ASA, tempo pré-op. } \\
\text { Age, gender, ASA, pré.op. time }\end{array}$ \\
\hline Koval & $\mathrm{R}$ & 490 & & & & & & & & & & hipoalbuminemia, leucopenia \\
\hline O'Hara & $\mathrm{R}$ & 9425 & & 447 & & & & & & & $\begin{array}{l}\text { tipo de anestesia } \\
\text { type of anesthesia }\end{array}$ & \\
\hline Ramnemark & $\mathrm{R}$ & 539 & & 26 & & & & & 109 & $65,3 \%$ em 5 anos $/$ years & & AVC \\
\hline Bovy & $\mathrm{R}$ & 187 & & & & & & & 36 & & & Idade/age, DA \\
\hline Clague & $\mathrm{R}$ & 622 & 73 & & & 128 & & & & & & $\mathrm{ASA}, \mathrm{CD}, \mathrm{DA}$ \\
\hline Grimes & $\mathrm{R}$ & 8383 & & 397 & & & & & & & tempo pré-op & \\
\hline \multirow[t]{2}{*}{ TOTAL } & & 24062 & $127 / 2298$ & $870 / 18347$ & & $212 / 1784$ & & $132 / 1227$ & $453 / 2354$ & $223 / 894$ & & \\
\hline & & & $5,52 \%$ & $4,74 \%$ & & $11,88 \%$ & & $10,76 \%$ & $19,24 \%$ & $24.94 \% \mathrm{em} 2$ anos $/$ years & & \\
\hline
\end{tabular}

$\mathrm{P}=$ prospectivo, $\mathrm{R}=$ retrospectivo, $\mathrm{FI}=$ fixação interna de fratura do colo femoral, $\mathrm{APQ}=$ artroplastia parcial do quadril, $\mathrm{ATQ}=$ artroplastia total do quadril, $\mathrm{DA}=$ doenças associadas, $\mathrm{CD}=$ cognição diminuída,. $\mathrm{U}=$ morte, $\mathrm{c}=$ contrôle, $\mathrm{c} 2$ = contrôle de 2 anos; pts $=$ pacientes

TABELA 1: Mortalidade e fatores relacionados

mês após a fratura; de $4,7 \%$, com três meses de $11,9 \%$, com seis meses de 10,8\%, com um ano de $19,2 \%$ e de $24,9 \%$ com dois anos. A taxa de mortalidade nos grupos-controle foi de $3,2 \%$ aos seis meses de seguimento, de 5,2\% ao final de um ano e de $9,6 \%{ }^{(11,17)}$ aos dois anos Os fatores correlacionados positivamente com a mortalidade que foram identificados com maior freqüência foram a idade avançada, presença de doenças associadas, deficiência cognitiva importante e sexo masculino.

\section{DISCUSSÃO}

Os índices de mortalidade nos pacientes geriátricos encontrados nesta revisão mostram que existe realmente uma influência importante da fratura do fêmur proximal na sobrevida destes pacientes, principalmente se compararmos com os índices encontrados na população sem fraturas. A taxa de mortalidade nos grupos-controle aos seis meses de seguimento é de $3,2 \%$, ao final de um ano de $5,2 \%$ e aos dois anos de $9,6 \%{ }^{(11,17)}$, bem menores que os encontrados nos pacientes com fratura, 10,8\%, 19,2\% e $24,9 \%$ respectivamente. Willig et al. . $^{(8)}$ encontram taxas de mortalidade nos pacientes com fratura que supera o grupo-controle em $4,5 \%$ no primeiro mês, $6,0 \%$ no terceiro, $3,5 \%$ no primeiro ano, $4,5 \%$ no segundo, $6,5 \%$ no quinto e $9,0 \%$ no sexto.

A idade elevada como fator determinante à maior mortalidade nos pacientes geriátricos com fratura do fêmur é citada por vários autores $^{(3,5,7,9,10,22,24)}$ e está em concordância com a literatura. Dois estudos merecem destaque. Enquanto Alarcón et al. ${ }^{(1)}$ concluem que pacientes com mais de 90 anos não apresentam taxa de mortalidade maior do que a normalmente encontrada two years later $24,9 \%$. In control groups the mortality rate was $3.2 \%$ six months following surgery, 5.2\% one year following surgery, and $9.6 "[11,17]$ two years following surgery. The factors positively correlated with mortality identified more frequently were: advanced age, presence of associated diseases, important cognitive deficiency and the masculine gender.

\section{DISCUSSION}

The mortality rate for the geriatric patients found in this revision show that there really is an important influence of the fracture of the proximal femur on the overlife of these patients, mainly if compared with the indexes found in the population without fractures. The mortality rate in the control groups at six months of follow-up is of $3,2 \%$, at the end of a year 5,2\% and after two years $9,6 \%{ }^{(11,17)}$, much smaller than found in the patients with fractures, 10,8\%, 19,2\% and $24,9 \%$ respectively. Willig et a ${ }^{8}$ find mortality rates in the patients with fracture that surpass the control group-control in $4,5 \%$ in the first month, $6,0 \%$ in the third, 3,5\% in the first year, $4,5 \%$ in the second, $6,5 \%$ in the fifth year, and $9,0 \%$ in the sixth year.

The high age as a decisive factor of the greater mortality in geriatric patients with a fracture of the femur is mentioned by several authors ${ }^{(3,5,7,9,10,22,24)}$, and is in agreement with the literature. Two studies deserve prominence: while Alarcón et al ${ }^{(1)}$ conclude that patients with more than 90 years don't present a mortality rate larger than usually found in the literature, Forster et $\mathrm{a}^{11}{ }^{11}$, when evaluating only patients over 100 years of age, show that $56 \%$ of the 
na literatura, Forster et al. ${ }^{(11)}$ ao avaliarem somente pacientes com mais de 100 anos de idade, mostram que 56\% dos pacientes morrem ao final de um ano, sendo esta taxa $20 \%$ maior que a mortalidade esperada para esta idade, de pessoas sem fratura do fêmur. A incidência de mortes durante a internação (31\%) neste grupo também é significativamente maior que no grupo geriátrico geral, ressaltando a necessidade de cuidados médicos intensos durante a internação hospitalar.

A existência de outras doenças crônicas nos pacientes idosos no momento da fratura é um fator prognóstico importante $\mathrm{e}^{(3,4,5,14,17,22,24)}$, sendo as afecções cardíacas e pulmonares, doenças renais, diabetes mellitus e acidente vascular cerebral (AVC) os de maior influência. Van Balen et al. ${ }^{(24)}$ citam que $67 \%$ dos pacientes tratados apresentam duas ou mais doenças associadas à fratura femoral. A taxa de mortalidade em quatro meses salta de zero para aqueles sem nenhuma doença associada para $4 \%$ quando uma, $15 \%$ quando duas, $26 \%$ quando três e $47 \%$ quando quatro ou mais doenças concomitantes à fratura femoral. Meyer et al. ${ }^{(17)}$ em seu trabalho com grupo-controle concluem que, na ausência de doenças associadas, deficiência de cognição e incapacidade física a taxa de mortalidade não se altera quando o idoso fratura o fêmur. A escala de risco anestésico da Sociedade Americana de Anestesia (American Society of Anestesiology) relaciona-se diretamente com a presença de um número maior de doenças crônicas, desta forma Dzupa et al. ${ }^{(9)}$ encontram uma incidência maior de mortes após a fratura do fêmur nos idosos com ASA maior. Aqueles com ASA 1 têm 0\%, ASA 2 têm 4,3\%, ASA 3 têm 21,3\%, ASA 4 têm $42,1 \%$ e ASA 5 têm $68,9 \%$ de mortalidade em um ano.

A capacidade cognitiva como fator preditivo da mortalidade nos idosos com fratura do fêmur é encontrada com freqüência nos estudos revisados ${ }^{(1,7,14,17,24)}$. Van Balen et al. ${ }^{(24)}$ utilizam o teste mini-mental de Folstein nas suas avaliações e obtêm um índice de mortalidade com quatro meses de $38 \%$ quando o resultado situa-se entre zero e 12, 12\% quando entre 13 e 18, 23\% quando entre 19 e 22 e apenas $2 \%$ quando entre 23 e 29. Cree et al. ${ }^{(7)}$ mostram que a média deste mesmo teste entre os sobreviventes após sofrerem uma fratura do fêmur é de 20 pontos, enquanto que entre os que morrem em três meses a média é de apenas nove pontos. luusko et al. ${ }^{(15)}$, em um trabalho comparativo prospectivo e randomizado, concluem que a reabilitação intensa após a fratura nos pacientes com demência leve ou moderada leva a uma sobrevida maior que naqueles que têm uma reabilitação padrão. O risco de morte nos pacientes com demência (10 a 12 pontos no teste de Engedal) é o dobro que nos pacientes lúcidos (15 pontos) (17). Como o aumento da mortalidade é mais evidente apenas nos seis primeiros meses após a fratura, discute-se se ela é decorrente de um déficit cognitivo temporário, ou seja delirium, e não de um estado mental diminuído previamente à fratura.

O sexo masculino foi mais susceptível em relação à mortalidade ${ }^{(3,5,7,8,9,11)}$. Enquanto uma mulher com fratura do fêmur proximal tem 1,5 vezes mais chance de morrer que uma sem fratura no período de dois anos, o homem tem sete vezes mais ${ }^{(11)}$. Em um trabalho tipo coorte prospectivo com grupo-controle, Fransen et al. ${ }^{(11)}$ encontra somente o sexo masculino como fator predisponente à morte, sendo que todos os outros itens estudados como idade, doenças associadas e deficiência cognitiva não têm influência. Davidson et al. ${ }^{(8)}$ relatam que a maior mortalidade masculina ocorre em todos os tipos de fratura do fêmur patients die at the end of one year, as this rate is $20 \%$ larger than the expected mortality for this age, for people without fractures of the femur. In this group, the incidence of deaths during hospitalization (31\%) is also significantly larger than in the general geriatric group, emphasizing the need of intense medical care during hospitalization

The existence of other chronic diseases in elderly patients at the moment of the fracture is an important prognostic factor ${ }^{(3,4,5,1417,22,24)}$, the heart and lung pathologies, renal diseases, diabetes mellitus and strokes (CVA) are the larger influence factors. Van Balen et al(24) mentions that $67 \%$ of the patients treated present two or more diseases associated to the femoral fracture. The mortality rate, in four months, jumps from zero (for those without any associated disease) to $4 \%$ when there is one, $15 \%$ when there are two, $26 \%$ when there are three and $47 \%$ when there are four or more diseases concomitant to the femoral fracture. Meyer et al(17) in the work with a control group concludes that, in the absence of associated diseases, of cognition deficiency and of physical impairment, the mortality rate is not altered when the elderly fractures the femur. The scale of anesthetic risk of the American Society of Anesthesia (ASA) is directly related to the presence of a larger number of chronic diseases. As such, Dzupa et al( ${ }^{(9)}$ find a larger incidence of deaths after the fracture of the femur in the elderly with larger ASA. Those with ASA 1 have $0 \%$, ASA 2 have $4,3 \%$, ASA 3 have $21,3 \%$, ASA 4 have $42,1 \%$ and ASA 5 have $68,9 \%$ mortality in one year.

The cognitive capacity, as a predictive factor of the mortality in the elderly with fracture of the femur is frequently found in the revised studies $^{(1,7,14,17,24)}$. Van Balen et a/(24) use Folstein's mini-mental test in their evaluations, and obtain a mortality rate, at four months, of $38 \%$ when the result is between zero and $12,12 \%$ when between 13 and 18, 23\% when between 19 and 22 and only $2 \%$ when between 23 and 29. Cree et al(7) show that the average for this same test among the survivors after a fracture of the femur is of 20 points, while among those who die in three months the average is of only nine points. luusko et $\mathrm{a}^{15}$, in a prospective comparative and randomized study, concluded that the intense rehabilitation after the fracture in the patients with light or moderate dementia leads to a longer survival rate than in those that have a standard rehabilitation. The death risk in the dementia patients (10 to 12 points in the Engedal test) is the double than in the lucid patients (15 points)(17). As the increase in mortality is more evident just during the first six months after the fracture, it is discussed if it is due to a temporary cognitive deficit, or delirium, and not of a reduced mental state previous to the fracture.

The masculine gender was more susceptive in relation to mortality $(3,5,7,8,9,11)$. While a woman with a fracture of the proximal femur has 1,5 times more chance of dying than without a fracture, within the period of two years, a man has seven times more ${ }^{(7)}$. In a prospective cohort study with a control group, Fransen(11) finds out that only the masculine gender as predisposition factor to death, and that all the other items studied, such as age, associated diseases and cognitive deficiency don't have any influence. Davidson et al(8) state that the largest masculine mortality occurs in all types of fracture of the proximal femur. Some hypotheses are placed to explain such fact $t^{(7)}$ : the man's fall is more traumatic than that of a woman. The man has more associated diseases or more serious cognitive deficiency. Cree (7) compares men with the same cognitive capacities and continues to obtain the 
proximal. Algumas hipóteses são levantadas para explicar tal fato ${ }^{(7)}$ : a queda do homem é mais traumática que da mulher, o homem tem mais doenças associadas ou deficiência cognitiva mais grave. Cree et al. (7) comparam homens com capacidades cognitivas iguais e continua obtendo a mesma diferença de mortalidade. Nenhum dos outros trabalhos revisados consegue explicar a causa desta diferença.

A capacidade deambulatória prévia à fratura do paciente é diretamente relacionada com a mortalidade ${ }^{(5,14,17)}$. São utilizados como parâmetros da capacidade de marcha a capacidade de caminhar fora da residência ${ }^{(17)}$ ou de andar sem nenhum tipo de suporte ${ }^{(5)}$. Aqueles idosos que conseguem andar fora de casa e têm uma fratura do fêmur apresentam risco de morte igual àqueles que não fraturam ${ }^{(17)}$.

Gruson et al.(13) estudam o efeito da presença da anemia no exame de entrada na internação dos idosos com fratura do fêmur. A anemia é considerada grave quando menor de $10 \mathrm{~g} / \mathrm{dl}$ e leve quando entre $10 \mathrm{~g} / \mathrm{dl}$ e $12 \mathrm{~g} / \mathrm{dl}$ nas mulheres, e entre $10 \mathrm{~g} /$ dl e $13 \mathrm{~g} / \mathrm{dl}$ nos homens. A taxa de mortalidade aos seis e doze meses após a fratura é diretamente proporcional ao grau de anemia. Um idoso com fratura do fêmur e anemia grave possui risco cinco vezes maior de morrer que um sem anemia. Como a necessidade de transfusão sangüínea ${ }^{(4)}$ é diretamente relacionada com o grau de anemia, pode-se inferir o risco de morte pela quantidade de sangue recebida pelo paciente durante a internação. Neste trabalho são excluídos os pacientes com demência, não-deambuladores e institucionalizados, ficando bem evidente a influência da anemia na mortalidade.

As fraturas do colo femoral do idoso têm como opções de tratamento a osteossíntese, a artroplastia parcial e a total do quadril. Apesar da necessidade de cirurgias de revisão serem mais freqüentes nos casos tratados com fixação da fratura, a taxa de mortalidade tardia (13 anos) é a mesma para todos os tratamentos ${ }^{(23)}$

Koval et al. ${ }^{(16)}$ correlacionam a hipoalbuminemia (nível de albumina sangüínea menor de 3,5 g/dl) e a linfopenia (dosagem de linfócitos totais no sangue menor de $1500 \mathrm{u} / \mathrm{ml}$ ) encontrados nos exames de entrada da internação com a mortalidade tardia. Estas alterações laboratoriais medem indiretamente o estado de desnutrição do paciente. A hipoalbuminemia predispõe a maior mortalidade durante a internação, enquanto que a linfopenia é preditiva de maior mortalidade um ano após a fratura. Os autores concluem que o prognóstico quanto a mortalidade pode ser dado através desses exames laboratoriais, de simples execução no ato da internação.

A anestesia regional no tratamento cirúrgico das fraturas do fêmur proximal do idoso é utilizada com freqüência muito maior que a geral no nosso meio. A idéia de que a primeira é bem mais segura que a segunda no paciente geriátrico é contraposta pelo trabalho de O'Hara et al. ${ }^{(18)}$ que estudam 9.425 pacientes idosos operados de fratura do fêmur. A mortalidade do grupo submetido à anestesia regional (3.219 pacientes) é igual à do grupo operado com anestesia geral (6.206 pacientes), sendo respectivamente de $5,4 \%$ e $4,4 \%$ em 30 dias. Apesar de ser um trabalho retrospectivo, a grande amostra populacional confere uma importância relevante ao estudo. Parker et al.(19) chegam à mesma conclusão em uma meta-análise incluindo 17 trabalhos comparativos e randomizados. Alguns destes trabaIhos mostram menor taxa de mortalidade no primeiro mês após a cirurgia quando se utiliza a anestesia regional, porém esta diferença não atinge o limite da significância same mortality difference. None of the other revised studies is capable of explaining the cause of this difference.

The walking ability previous to the patient's fracture is directly related to the mortality ${ }^{(5,14,17)}$. They are used as parameters of the marching capacity, the capacity to walk out of the residence(17) or of walking without any type of support ${ }^{(5)}$. The elderly that get to walk out of house and have a fracture of the femur, present the same death risk as those that don't have a fracture ${ }^{(17)}$.

Gruson et al(13) study the effect of the presence of the anemia at the initial examination at the time of the hospitalization of the elderly with a fracture of the femur. Anemia is considered as serious when less than $10 \mathrm{~g} / \mathrm{dl}$ and light when among $10 \mathrm{~g} / \mathrm{dl}$ and $12 \mathrm{~g} / \mathrm{dl}$ in women, and between $10 \mathrm{~g} / \mathrm{dl}$ and $13 \mathrm{~g} / \mathrm{dl}$ in men. The mortality rate at six and twelve months after the fracture is directly proportional to the degree of anemia. An elderly with a fracture of the femur and serious anemia has five times more risks of dying than one without anemia. Because the need of blood transfusion is directly related to the degree of anemia, the risk of death can be inferred by the amount of blood(4) received by the patient during hospitalization. The patients with dementia, non-walkers and institutionalized, with a clear evidence of the influence of anemia in the mortality rate, are excluded from this study.

The fractures of the collum femoris in the elderly have osteosynthesis, partial and total hip arthroplasty as treatment options. In spite of the more frequent need for revision surgeries in cases treated with the fixation of the fracture, the rate of late mortality (13 years) it is the same for all of the treatments ${ }^{(23)}$.

Koval et a/(16) correlate hypalbuminemia (level of blood albumin below 3,5 g/dl) and the lymphopenia (dosage of total blood lymphocytes less than $1500 \mathrm{u} / \mathrm{ml}$ ) found in the initial examinations at the time of hospitalization with late mortality. These laboratory alterations indirectly measure the state of the patient's malnutrition. The hypalbuminemia predisposes an increased mortality during hospitalization, while lymphopenia is a predictive of increased mortality one year after the fracture. The authors conclude that the prognostic regarding mortality can be presented through those simple laboratory exams, at the time of hospitalization.

Regional anesthesia in the surgical treatment of the fractures of the proximal femur in the elderly is used with much more frequency than the general in our area. The idea that the first option is much safer than the second one for the geriatric patient is opposed by the study of O'Hara's et al(18), that studied 9.425 elderly patients operated from a fracture of the femur The mortality of the group submitted to the regional anesthesia (3.219 patients) is same as of the group operated with general anesthesia (6.206 patients), respectively 5,4\% and $4,4 \%$ in 30 days. In spite of being a retrospective study, the large population sample confers a relevant importance to the study. Parker et al(19) reach the same conclusion in a meta-analysis including 17 comparative and randomized studies. Some of these studies show a smaller mortality rate in the first month after the surgery when the regional anesthesia is used. However this difference does not reach a limit of significance.

In a retrospective study, Ramnemark et al(21), show the influence of CVA in the evolution of elderly patients with a fracture of 
Ramnemark et al. ${ }^{(21)}$ em um estudo retrospectivo mostram a influência do AVC na evolução dos pacientes idosos com fratura do colo femoral. São comparados 392 pacientes só com fratura do colo femoral com 147 pacientes portadores de AVC e fratura, e a taxa de mortalidade ao final de um ano aumenta de $16,8 \%$ para 29,3\% respectivamente. Mesmo quando se faz um ajuste para o sexo, a diferença continua significante. A maior mortalidade talvez possa ser explicada pela capacidade deambulatória prejudicada que os pacientes com AVC apresentam antes da fratura, característica que não é estudada separadamente neste trabalho.

O tempo decorrido entre a fratura e a cirurgia parece não ser importante na mortalidade dos idosos com fratura do fêmur, conforme conclui Grimes et al.(12), após estudo com 8.383 pacientes. Os pacientes são divididos em três grupos, sendo o primeiro operado no período de 24 horas após a fratura, o segundo após as 24 horas, porém sem patologia ativa e o terceiro também após 24 horas e com patologia ativa. Entende-se por paciente sem patologia ativa aquele que tem a cirurgia adiada por motivos não médicos, como por exemplo falta de vaga na sala de operações ou impedimentos burocráticos. Os pacientes com patologia ativa têm a cirurgia postergada por doenças que estão descompensadas temporariamente. A mortalidade encontrada no grupo operado rapidamente (menos de 24 horas) aparentemente é menor, porém quando se homogeneíza os grupos quanto a presença de doenças associadas esta diferença desaparece.

Como parece haver uma relação direta da mortalidade do idoso com fratura do quadril com a desnutrição(16), vários autores tentam verificar a influência da alimentação no prognóstico a longo prazo destes pacientes. A suplementação da alimentação com proteínas, vitaminas e sais minerais é estudada em uma meta-análise por Avenell et al.(2), e apesar da baixa qualidade dos trabalhos em termos metodológicos, conclui-se não haver diferenças na mortalidade entre os pacientes alimentados regularmente e os com suplementação.

Parker et al. ${ }^{(20)}$ mostram que não existem evidências literárias de que o tratamento cirúrgico das fraturas do fêmur proximal no idoso diminua a mortalidade em relação ao tratamento conservador. Neste trabalho de meta-análise os autores selecionaram os trabalhos randomizados e quase-randomizados que comparam esses dois tipos de tratamento, e encontram apenas cinco estudos, envolvendo 428 pacientes. Além disso, a maioria destes trabalhos apresentam metodologia científica de baixa qualidade, segundo a avaliação dos autores. Novos trabalhos comparativos seriam necessários para confirmar esse achado, porém é muito difícil atualmente indicar um tratamento conservador para um idoso hígido. Esta revisão é importante pois nos permite optar pelo tratamento conservador em alguns casos selecionados de fratura do quadril, como por exemplo nos idosos com algum impedimento para a cirurgia.

\section{CONCLUSÃO}

Podemos concluir que a literatura recente identificou quatro grandes fatores relacionados diretamente com a mortalidade nas fraturas do fêmur proximal do idoso, idade avançada do paciente, presença de doenças associadas, sexo masculino e existência de deficiências cognitivas. A mortalidade intra-hospi- the collum femoris. Three hundred and ninety two patients are compared with only a fracture of the collum femoris, to 147 patients with CVA and fracture, and the mortality rate at the end of one year increases, respectively, from $16,8 \%$ to $29,3 \%$. Even when an adjustment is made as to the gender, the difference continues significant. The increased mortality may be explained by the impaired waking ability that patients with CVA present before the fracture, a characteristic that is not individually studied in this assay.

The time elapsed between the fracture and the surgery seems not to be important in the mortality rate for the elderly with a fracture of the femur, as concluded by Grimes et al2, after a study with 8.383 patients. The patients were divided into three groups. The first was operated in the period of 24 hours after the fracture. The second after the 24 hours, but presented no active pathology. The third group was also operated after 24 hours, but presented active pathology. It is understood that a patient without active pathology is the patient whose surgery is postponed for non-clinical reasons, such as, for instance, lack of vacancy in the operating room or bureaucratic impediments. The patients with an active pathology have the surgery postponed by diseases that are temporarily decompensated. The mortality found in the group operated quickly (less than 24 hours) is seemingly smaller. However, when the groups are homogenized as to the presence of associated diseases, this difference disappears.

As there seems to be a direct relationship of the mortality in elderly with a fracture of the hip and malnutrition ${ }^{(16)}$, several authors try check on influence of feeding in the long term prognostic of these patients. Food supplementation with proteins, vitamins and mineral salts was studied in a meta-analysis by Avenell et $\mathrm{al}^{(2)}$ and, in spite of the low quality of the studies in methodological terms, it was concluded that there are no differences in the mortality among patients fed regularly and patients receiving supplements.

Parker et al(20) show that there are no literary evidences that the surgical treatment of the fractures of the proximal femur in the elderly reduces the mortality, in relation to the conservative treatment. In this meta-analysis study the authors selected the randomized and quasi-randomized studies that compare those two types of treatment, and found only five studies, involving 428 patients. In addition, most of these studies present a low quality scientific methodology, according to the authors' evaluation. New comparative studies would be necessary to confirm these findings. However it is very difficult, at this time, to indicate a conservative treatment for a higid elderly. This review is important because it allows us to choose the conservative treatment in some selected cases of fracture of the hip, as for instance in the elderly with some impediment for the surgery.

\section{CONCLUSION}

We can conclude that the recent literature identified four great factors directly related with the mortality in elderly with a fracture of the proximal femur, the patient's advanced age, presence of associated diseases, of the masculine gender and the existence of cognitive deficiencies. The intra-hospital mortality, until 
talar, ao fim de um mês, três meses, seis meses, um ano e dois anos foram respectivamente $5,52 \%, 4,74 \%, 11,88 \%, 10,76 \%$ $19,24 \%$ e $24,94 \%$. Outros fatores determinantes na mortalidade como capacidade deambulatória prévia à fratura, índice ASA, anemia, hipoalbuminemia, linfopenia e existência de AVC foram encontrados em alguns trabalhos isolados. Não apresentaram correlação com a mortalidade o tipo de tratamento cirúrgico nas fraturas do colo femoral, o tipo de anestesia utilizada e o tempo decorrido antes da cirurgia. the end of one month, three months, six months, one year and two years were 5,52\%, 4,74\%, 11,88\%, 10,76\% 19,24\% and 24,94\% respectively. Other decisive factors in the mortality, such as walking ability capacity previous to the fracture, ASA index, anemia, hypalbuminemia, lymphopenia and the existence of CVA were found in some isolated studies. The type of surgical treatment in the fractures of the collum femoris, the type of anesthesia used and the time elapsed before the surgery didn't present a correlation with the mortality.

\section{REFERÊNCIAS BIBLIOGRÁFICAS}

1. Alarcon T, Gonzalez-Montalvo JI, Barcena A, Saez P. Further experience of nonagenarians with hip fractures. Injury 32:555-558, 2001.

2. Avenell $\mathrm{A}$, Handoll $\mathrm{HH}$. Nutritional supllementation for hip fracture aftercare in the elderly. Cochrane Database Syst Rev 1:CD001880, 2004.

3. Bovy P, Jolly S, Dropsy S, Sacre F. Results of rehabilitation on quality of walking and outcome in elderly patients following femoral neck fracture. Development after one year]. Ann Readapt Med Phys 45:19-25, 2002.

4. Carson JL, Terrin ML, Barton FB et al. A pilot randomized trial comparing symptomatic vs. hemoglobin-level-driven red blood cell transfusions following hip fracture. Transfusion 38:522-529, 1998.

5. Chariyalertsak S, Suriyawongpisal P, Thakkinstain A. Mortality after hip fractures in Thailand. Int Orthop 25:294-297, 2001.

6. Clague JE, Craddock E, Andrew G, Horan MA, Pendleton N. Predictors of outcome following hip fracture. Admission time predicts length of stay and inhospital mortality. Injury 33:1-6, 2002.

7. Cree M, Soskolne CL, Belseck E et al. Mortality and institutionalization following hip fracture. J Am Geriatr Soc 48:283-288, 2000.

8. Davidson CW, Merrilees MJ, Wilkinson TJ, McKie JS, Gilchrist NL. Hip fracture mortality and morbidity-can we do better? NZ Med J 114:329-332, 2001.

9. Dzupa V, Bartonicek J, Skala-Rosenbaum J, Prikazsky V. [Mortality in patients with proximal femoral fractures during the first year after the injury]. Acta Chir Orthop Traumatol Cech 69:39-44, 2002.

10. Forster MC, Calthorpe D. Mortality following surgery for proximal femoral fractures in centenarians. Injury 31:537-539, 2000.

11. Fransen M, Woodward M, Norton R, Robinson E, Butler M, Campbell AJ Excess mortality or institutionalization after hip fracture: men are at greater risk than women. J Am Geriatr Soc 50:685-690, 2002.

12. Grimes JP, Gregory PM, Noveck H, Butler MS, Carson JL. The effects of timeto-surgery on mortality and morbidity in patients following hip fracture. Am J Med 112:702-709, 2002

13. Gruson KI, Aharonoff GB, Egol KA, Zuckerman JD, Koval KJ. The relationship between admission hemoglobin level and outcome after hip fracture. J Orthop Trauma 16:39-44, 2002.
14. Hannan EL, Magaziner J, Wang JJ et al. Mortality and locomotion 6 months after hospitalization for hip fracture: risk factors and risk-adjusted hospital outcomes. JAMA 285:2736-2742, 2001.

15. luusko TM, Karppi P, Avikainen V, Kautiainen H, Sulkava R. Randomised clinically controlled trial of intensive geriatric rehabilitation in patients with hip fracture: subgroup analysis of patients with dementia. BMJ 321:1107-1111, 2000.

16. Koval KJ, Maurer SG, Su ET, Aharonoff GB, Zuckerman JD. The effects of nutritional status on outcome after hip fracture. J Orthop Trauma, 13:164 169, 1999.

17. Meyer HE, Tverdal A, Falch JÁ, Pedersen Jl. Factors associated with mortality after hip fracture. Osteoporos Int. 11:228-232, 2000.

18. O'hara DA, Duff A, Berlin JÁ. The effect of anesthetic technique on postoperative outcomes in hip fracture repair. Anesthesiology 92:947-957, 2000

19. Parker MJ, Handoll HH, Griffiths R. Anaesthesia for hip fracture surgery in adults. Cochrane Database Syst Rev 4:CD000521, 2001.

20. Parker MJ, Handoll HH, Bhargara A. Conservative versus operative treatment for hip fractures. Cochrane Database Syst Rev 4:CD000337, 2000

21. Ramnemark A, Nilsson M. Borssen B, Gustafson Y. Stroke, a major and increasing risk factor for femoral neck fracture. Stroke 31:1572-1577, 2000

22. Raunest J, Engelmann R, Jonas M, Derra E. [Morbidity and mortality in paraarticular femoral fractures in advanced age. Results of a prospective study] Unfallchirurg 104:325-332, 2001

23. Ravikumar KJ, Marsh G. Internal fixation versus hemiarthroplasty versus total hip arthroplasty for displaced subcapital fractures of femur-13 year results of a prospective randomised study. Injury 31:793-797, 2000.

24. Van Balen R, Steyerberg EW, Polder JJ, Ribbers TL, Habbema JD, Cools HJ Hip fracture in elderly patients: outcomes for function, quality of life, and type of residence. Clin Orthop 390:232-243, 2001

25. Willig R, Keinanen-Kiukaaniemi S, Jalovaara P. Mortality and quality of life after trochanteric hip fracture. Public Health 115:323-327, 2001. 